\title{
NEWS OF THE ASSOCIATION
}

\author{
BALANCE SHEET
}

for the years ended 31 December 1988 and 1987

\section{Asse ts}

\begin{tabular}{|c|c|c|}
\hline & 1988 & 1987 \\
\hline \multicolumn{3}{|l|}{ Current Assets: } \\
\hline Cash and cash equivalents & $\$ 156,861$ & $\$ 120,349$ \\
\hline Accounts receivable & 7,370 & 6,231 \\
\hline Prepaid expenses & 1,159 & - \\
\hline Total Current Assets & 165,390 & 126,580 \\
\hline Office Equipment & 32,464 & 127,291 \\
\hline Less Accumulated Depreciation & 21,241 & 16,695 \\
\hline \multirow[t]{2}{*}{ Net office equipment } & 11,223 & 10,596 \\
\hline & $\$ 176,613$ & $\$ 137,176$ \\
\hline
\end{tabular}

LIABILITIES AND FUND BALANCE

Current Liabilities:

\begin{tabular}{lrr} 
Accounts payable & $\$ 30,255$ & $\$ 23,984$ \\
Prepaid dues & 5,555 & 8,770 \\
Unmatched grant funds & 6,872 & 8,371 \\
Long-term debt, due within one year & 1,444 & - \\
\multicolumn{1}{c}{ Total current liabilities } & 44,126 & 41,125 \\
g-term debt, due after one year & 2,056 & - \\
d Balance & $\underline{130,431}$ & $\underline{9176,051}$ \\
& $\underline{\$ 137,176}$ \\
\hline
\end{tabular}

STATEMENTS OF REVENUES, EXPENSES, AND FUND BALANCE

\section{8}

$\$ 234,945$

Revenues:

Expenses:

Publication costs, Cambridge University Press

Other publication and distribution costs

Other awards and grants

Administrative services

Professional services

Other fees and honoraria

Program committee and board meetings

Secretarial services

Fund raising expenses

Office supplies and expense

Carried forward

$\begin{array}{rr}41,425 & 37,369 \\ 28,661 & 18,930 \\ 1,996 & 500 \\ 25,112 & 13,183 \\ 6,910 & 8,070 \\ 26,112 & 17,920 \\ 15,804 & 9,214 \\ 15,515 & 18,344 \\ 10,228 & 15,770 \\ 8,554 & 12,768 \\ 180,317 & 152,068\end{array}$




\begin{tabular}{lrr} 
& \multicolumn{1}{c}{$\mathbf{1 9 8 8}$} & $\mathbf{1 9 8 7}$ \\
Brought forward & 180,317 & 152,068 \\
Postage & 9,591 & 6,576 \\
Telephone & 4,083 & 4,542 \\
Depreciation & 4,546 & 4,232 \\
Miscellaneous expenses & 756 & 771 \\
Loss on investments & 875 & 9,412 \\
$\quad$ Total expenses & 200,565 & 177,601 \\
Excess of revenues over expenses & 34,380 & 5,822 \\
Fund balance, beginning of year & $\underline{96,051}$ & 90,229 \\
Fund balance, end of year & $\underline{\$ 130,431}$ & $\underline{\$ 96,051}$ \\
\hline
\end{tabular}

\section{STATEMENT OF CASH FLOWS}

NET INCREASE IN CASH

1988

1987

Cash flows from operating activities:

Excess of revenues over expenses

$\$ 34,380$

$\$ 5,822$

Adjustments to reconcile excess of revenues over expenses to cash provided from operating activities:

Depreciation

Increase in accounts receivable

(Increase), decrease in prepaid expenses

Increase in accounts payable

Increase, (decrease) in prepaid dues

Increase, (decrease) in unmatched grant funds

Net cash provided from operating activities

17,558

2,615

4,226

Cash flows from investment activities:

Purchase of equipment

35,663

Cash flows from financing activities:

Borrowing from long-term debt

Principal payments of long-term debt

Net cash provided from financing activities

Net increase in cash

Cash, beginning of year

Cash, end of year

\begin{tabular}{|c|c|}
\hline $\begin{array}{c}4,479 \\
(979)\end{array}$ & - \\
\hline 3,500 & - \\
\hline 36,512 & 27,807 \\
\hline 120,349 & 92,542 \\
\hline$\$ 156,861$ & $\$ 120,349$ \\
\hline
\end{tabular}

\section{NOTES TO FINANCIAL STATEMENTS}

1. Summary of Significant ACCOUNTING POlicies. Basis of presentation. The accompanying financial statements have been prepared on the accrual basis of accounting and in accordance with the standards of accounting and financial reporting under the $A I C P A A$ udit Guide, Audits of Certain Nonprofit Organizations.

Office equipment is carried at cost. Depreciation is computed using the straight-line method based on the estimated useful lives of three and five years.

Revenues. Membership dues and grants are recognized as revenue in the applicable membership and grant period.

Donated services consists of wages and benefits for employees working for MESA but paid by the University of Arizona. Office space is also provided, however, a value has not been determined. 
2. Organization. The Middle East Studies Association of North America (MESA) was organized in 1966 by a group of American and Canadian scholars to promote high standards of scholarship and instruction in Middle East studies, to facilitate communication among scholars through meetings and publications, and to foster cooperation among persons and organizations concerned with the scholarly study of the Middle East. Membership includes subscriptions to the International Journal of Middle East Studies, the MESA Bulletin, and the Newsletter.

MESA obtained an exemption from income tax under the Internal Revenue Code Section 501 (c)(3) and as such is exempt from Federal and State income tax.

3. UNMATCHED GRANT FUNDS. MESA was awarded a National Endowment for the Humanities Challenge Grant in December 1984. To earn one dollar from the grant MESA must receive three dollars of qualified outside funds. The balance of unmatched grant funds represent amounts received from the NEH for which matching funds have not yet been received. Should MESA fail to meet the matching requirements during the grant period, any unmatched funds must be returned to the NEH.

4. Commitments AND AGRements. MESA has an agreement with the Syndics of the Press of Cambridge University (Syndics) to publish and distribute the International Journal of Middle East Studies and the MESA Bulletin to each member. Annually an allocable dollar amount of membership dues are paid to Syndics to cover the cost of the subscription.

5. LONG-TERM DEBT. The details of long-term debt are as follows:

$11.55 \%$ equipment installment contract, payable $\$ 148$ per month $P$ \&I

1088

1987

Less amounts due within one year

$\$ 3500$

1444

Amount due after one year

The annual maturities are as follows:

1989

1990

$\$ 1444$

1620

1991

436

$\$ 3500$

\section{SUPPLEMENTARY INFORMATION}

Statements of Revenues

Membership dues - individual

Membership dues - institutional

1988

1987

Contributions

National Endowment for the Humanities

Challenge Grant

Donated services, University of Arizona

Annual meeting, net of expense

Publications sales

Mailing list sales

$\$ 94,620$

22,000

$\$ 79,461$

11,223

22,250

17,584

Advertising income

15,156

15,774

40,627

31,527

30,780

2,735

5,606

2,355

3,445

2,965

1,850

1,350

Interest income

Total revenues 